Karen Korning Zethsen*

\title{
The Dogmas of Technical Translation - Are They Still Valid?
}

\begin{abstract}
Technical texts are generally considered to be informative, objective and devoid of expressive features. In this paper I shall argue in favour of the more recent assertion that technical texts are not only concerned with the transfer of facts, but - like texts in general - serve various communicative purposes. The aim of my work is to increase the awareness of the translation scholar and the professional translator of the fact that literary texts do not hold a monopoly on expressivity and creativity and that also within the framework of technical translation the expressive function must be expected, noticed and translated. I shall furthermore argue that "technical texts" do NOT constitute a genre - on the contrary a great variety of genres make use of technical language.
\end{abstract}

\section{Introduction}

The following paper is based on a chapter from my ph.d. thesis "Expressivity in Technical Texts - from a Translation Theoretical Perspective", 1997 and a paper given at Heriot-Watt University, Edinburgh, 1998. 1

In my thesis I define and describe the concept of expressivity and in my analyses I provide evidence for the fact that expressivity does abound in so-called technical texts and I argue that the expressive function is not per definition inferior to the informative function in technical texts.

In this paper I will try to restrict myself to dealing with the present state of technical translation. In order to do that it is necessary as a

1 at the Postgraduate Forum on Translation, Interpreting, and Contrastive/CrossCultural Studies, 28-29 November, 1998.

* Karen Korning Zethsen

Engelsk Institut

Handelshфjskolen i Århus

Fuglesangs Allé 4

DK-8210 Arhus V 
66

starting point to attempt an outline of the conventional description of technical texts and their authors.

\section{The Prototypical Technical Text}

Traditionally ${ }^{2}$ technical texts are defined on the basis of subject-matter, terminology and a number of typical syntactic features such as:

nominalisation

heavy pre- and postmodifications

extensive use of passives

use of third person

long and complex sentences

In addition, technical texts are described as being almost totally dominated by the informative function ${ }^{3}$.

So according to the traditional view, the purpose of a technical text is to transmit objective information on a technical subject. To this end a relatively standardised syntax and style are applied ${ }^{4}$.

According to Baakes (1994: 3) technical texts are characterised by:

“...objectivity, absence of expressiveness and emotion, precision, economy, conciseness, and formality..."

As to technical text types the following are often cited and analysed as typical examples of technical texts:

scientific articles

text books

manuals

encyclopedias

specifications

patent applications, etc.

2 See e.g. Bell 1991:203, Norlyk 1994:25, Munck 1994:139-71, Newmark 1988:151.

3 See e.g. Gottlieb 1994:47, Nord 1991:178, 182, Myers 1989:3, Newmark 1988:40 and Baakes 1994:5.

4 See Wilss 1996:22-23 and Laurén 1998:463. 


\section{The Technical Writer}

The stereotyped writer of technical texts is a factual and objective engineer who is not particularly aware of or interested in the target group of his text and whose only aim is to transmit the technical information of the text in question - and again Baakes (1994):

"Scientists and engineers are trained to be objective and to accept as facts only impersonal, objective statements about things which can be seen by any observers who choose to look. This objective attitude is naturally reflected in the way they express themselves..." (Baakes 1994: 3 - my emphasis)

"In their work scientists and engineers aim at communicating primarily with other scientists and engineers. Normally, they do not need to make the subject they are dealing with seem interesting or exciting, since they are writing or speaking to those who have chosen to read or listen." (ibid. - my emphasis) ${ }^{5}$

Furthermore, he - the technical writer - is often described as a rather unskilled or even incompetent writer:

"Perhaps inevitably a technical translation [in this context meaning text to be translated - KKZ] is so varied in topic and often diverse in register, and so badly written, that it is not easy to make helpful generalisations about it.” (Newmark 1988: 160 - my emphasis)

\section{The State of Technical Translation}

These views on the nature of technical texts and technical writers are bound to influence the way we perceive (or used to perceive I would like to say) the translation of technical texts.

During the 20th century the number of technical texts which are translated has exploded as a result of industrialisation and increased international business and cooperation - most recently as a result of the requirements of the EU machinery directive of 1989. Today technical

5 Baakes' statements embody the view of the standard prescriptive text book on technical writing. In the words of Halloran \& Bradford (1984: 180): "From the side of rhetoric, a long-standing tradition holds that devices of eloquence are inappropriate for scientific discourse, and the standard textbooks in scientific and technical writing continue to take this position". And furthermore: "Modern science has been slow to acknowledge its use of figurative expression, probably due to the long-standing tradition which contends that the figures are not suitable for scientific and technical discourse." (ibid.) 
translation constitutes the vast majority of the professional translator's workload.

In 1813 Schleiermacher (according to Snell-Hornby 1988: 11) considered the translation of LSP texts as "mundane and mechanical matters unworthy of scholarly attention." Though today we cannot say that the translation of LSP texts is considered unworthy of scholarly attention I am afraid that it still has a certain reputation for being mundane and mechanical - this is a translation of a quotation from a Danish doctoral thesis from 19946:

“...technical, informative texts. Such texts - as e.g. declarations of contents and instructions for use - refer to phenomena which exist independently of the language culture in which they exist - or are invented. We are dealing with totally predictable texts! They can be translated without linguistic intuition, completely mechanically. The necessary tools are simply word lists, word frequency lists and grammatical formulas. This is precisely why one can expect to translate these kinds of text by means of a computer. All other text types have to be translated by humans" (Gottlieb 1994: 47)

Terminology is generally considered the main challenge of the technical translator (see e.g. Newmark 1988: 152) and much LSP research has consequently been carried out within this field ${ }^{7}$.

In translation-oriented text typologies (which have been very influential - and much criticised - since Katharina Reiss ${ }^{8}$ published the first in 1971) ${ }^{9}$ technical texts - and thus technical translation - are often cited as a kind of counter example to literary translation - the point being that

\footnotetext{
6 My translation.

7 Hoffmann 1991: 158.

8 No doubt if one goes further back the views of Reiss reflect earlier views on technical translation. See e.g. Halloran \& Bradford (1984), who go as far back as Aristotle.

9 The translation-oriented text typologies have no doubt done much harm in relation to technical texts. The fact that technical texts are automatically classified as being informative has greatly influenced the way in which technical texts have generally been perceived. Some might claim that the texts are only classified according to their dominant function, but one could question whether such a classification is possible. How does one assess which function is most important in a text - is it necessarily the one that takes up most space? Bühler and Jakobson's well-known language functions are very useful concepts for the description of functions present in a text, but as the basis of a translation-oriented classification I believe they are of no value (for further discussion of this subject see Korning Zethsen 1997: 53ff)
} 
literary translation is very creative - an art - whereas technical translation is almost mechanical and definitely not more than a craft:

"... literary translation, traditionally the province of poets and scholars and once the only area thought worthy of the theorist, and...special language translation, traditionally inferior and the main concern of the translation schools.” (Snell-Hornby 1988: 33)

“...so much more direct, so much freer from alternatives, so much less artistic than the translation of any other kind of prose." (Savory 1968: 161)

Also within the field of translation didactics the polarisation literature/LSP has been influential:

“... where the [text - KKZ] typologies were set up as part of a programme of translator-training, they were used as a means of grading texts by ranking them along a scale of "difficulty" and "loss" from the extreme of poetry, through other literature, other texts and scientific and technical to mathematical texts which appear to be the least "difficult" and in which there is virtually no "loss"." (Bell 1991: 203)

\section{The Dogmas of Technical Translation}

To sum up technical translation seems to be subject to the following dogmas:

\section{The purpose of the translation is to transmit factual infor- mation.}

2. The greatest problem is terminology.

3. No particular translation strategy is needed as long as the translator is familiar with the relevant terminology and the typical syntax of a technical text.

and the traditional view of technical texts is based on the assignment of all technical texts to the informative text type and this assignment is then again based on a rather limited number of technical texts which have acquired the status of prototypical technical texts. The text type conventions of the prototypes, the stereotypical view of the technical writer, the focus on terminology and the convenient polarisation literature/science-technology have all contributed to the rather narrow perception of technical texts which has prevailed for many years. It goes without saying that the dominant view of technical translation has been equally narrow. 
The technical text type which is probably cited most frequently is the scientific article (often in general works on translation theory, which are not specially interested in technical language), though it is in no way important to the professional translator as far as bulk is concerned. The stereotyped text types I mentioned in the beginning of this talk do of course exist and especially manuals and specifications constitute an important part of the translator's workload. However, in general one may suspect that many of the texts subjected to analyses by scholars have been chosen because they were easily accessible (and well-known to the researcher) and not because they were representative of the reality of the professional technical translator (and the same seems to apply for translation didactics - see Hoffmann 1991: 158).

\section{The Technical Genre(s) - Singular or Plural?}

Today the texts translated by translators specialised in technical translation typically include (apart from those mentioned in the beginning of this paper):

technical reports

brochures

annual reports

letters

minutes of meetings

manuscript speeches, etc., etc.

The above texts represent a much broader range of texts than are traditionally provided as examples of technical texts and though no doubt there is still a core of technical text types which correspond to the traditional definition this calls for an extension of the notion of technical texts for pragmatic reasons. One might say that the traditional technical texts such as scientific articles, manuals and patent applications did once represent the prototypical technical texts - naturally with a pertaining number of blurred edges. Today, however, it seems that the blurred edges have by far outnumbered the former prototypes.

So, my question is do we really need - for translational purposes - to define what a technical text is? Shouldn't we rather be concerned with the fact that technical language is used in numerous genres all serving 
a multitude of purposes. Evidently, technical language has all sorts of characteristics, but that is not the same as claiming that texts which make use of technical language do all belong to the same genre. And that is precisely what seems to be the case. The expression "technical texts" is used for all texts which make use of technical language and which exist within a technical knowledge area and this group of texts is treated as being homogeneous to a large extent which is very misleading to the translator.

\section{The Purpose of Technical Texts}

That many - but of course not all - writers of technical texts are trained in the natural sciences and not in communications or linguistics and consequently are not too good at expressing themselves in writing must be considered a fact. However, one cannot from this naturally draw the conclusion that these writers have no other aims than the transfer of technical information nor that they are not trying - like non-technical writers - to promote these other aims in their texts:

"...texts can be seen as the result of motivated choice: producers of texts have their own communicative aims and select lexical items and grammatical arrangements to serve those aims" (Hatim \& Mason 1990: 4)

And like Laurén (1998: 465) we may ask in disbelief "Are there really no individualists behind LSP texts?"

By way of illustration the non-informative purposes which I keep claiming that a text may have could at a general level belong to one of the following groups:

\section{Strengthening the author's image}

2. Strengthening the image of the company

3. Obtaining financial support

\section{Selling a product or knowhow}

As the financial side of the matter is crucial, we may assume that points 3 and 4 often make use of points 1 and 2 . Or that what points 1 and 2 have obtained at an earlier occasion (in other texts) may later on serve to obtain points 3 and 4 etc., etc. 
Fortunately it has become increasingly clear to many scholars that literary texts do not hold a monopoly on expressivity and creativity. As early as in 1969 Newmark (1969: 80) writes:

"...the common assumption that scientific and technical writing is concerned only with facts...is misplaced"

and according to Hatim \& Mason (1990: 2):

"...the boundary between "literature" and "non-literature" is an artificial one and if "creative use of language" is taken to be one of the criteria for recognition of the former, it can be shown that many nonliterary texts display the same creative devices, used to the same ends, as in what is recognised as belonging to the category "literature".

And finally Brown 1996: 37:

"The traditional view of objective, a-rhetorical scientific discourse...has come increasingly into question..."

\section{The Dogmas of Technical Translation Revisited}

In the beginning of this paper I established 3 dogmas of technical translation and in the title of my paper I ask "are they still valid". As you may have gathered by now I do not think so. On the contrary I find them outdated, useless and even misleading. Let me briefly comment on them again.

\section{$\operatorname{Re} 1$.}

Undoubtedly, a very important purpose of most technical texts and translations is to convey factual information. However, as I have just argued, it is rarely the sole purpose of any text and whether it is always the main purpose is a moot point. In my thesis I argue that technical texts are multifunctional to an extent which is highly relevant for the translator. The constant focus on the informative function within technical translation has weakened the translator's expectations and awareness of other important functions. For the translator it is crucial to be aware of "the view lately current in rhetoric and composition theory":

"- namely that scientific and technical discourse is subject to the same slants, biases, and marketplace influences as any other kind of discourse -" (Brown 1996: 46) 
Re 2.

If the only relevant purpose of a technical translation is to transmit information it follows naturally that terminology is the greatest problem. Terminology is evidently a difficult and time-consuming area for the technical translator. However, the more we become aware of the fact that technical texts often serve several important functions the more time is spent unveiling the linguistic devices applied in order to further these functions, especially as expressivity in technical texts is often more subtle than in other kinds of text.

Technical terminology has been a favorite research area to LSP researchers and much important research has been carried out within this field, but unfortunately this focus on terminology has also (according to Hoffmann 1991) lead to a state of lexicocentrism. The hunt for terminology has overshadowed the fact that there is something between the terms which is equally important for a satisfactory translation. Instead of considering a technical text as a collection of technical terms ${ }^{10}$ it should be seen as a text - i.e. as an entity written to serve various purposes. Awareness of these purposes cannot be reached by focussing on terminology and by working from sentence to sentence, but only by applying a textual approach (Hoffmann 1991: 158) ${ }^{1112}$. The real challenge for the technical translator of today is the combination of often highly-specialised terminology and expressive features.

\section{Re 3.}

It is beyond questioning that a great many technical texts are subject to certain text type conventions and that to a certain extent knowledge of

10 As pointed out by Newmark the average technical text contains no more than perhaps 5-10\% technical terminology "The rest is "language"..." (Newmark 1988: 160).

11 See also Kewley-Draskau 1994: 106.

12 In a paper titled "Culture in scientific and technical communication: A dynamic view from a translation perspective" (1998, unpublished) Hatim argues along the same lines. According to Hatim the specific domain of scientific and technical communication has traditionally been seen almost exclusively in terms of terminology and level of formality and/or technicality. Instead he suggests that from a translation perspective focus should be shifted from terminology to "...those neglected aspects of textual practices (the discourse, the genre and the actual texts that typify scientific communication, for example) which ultimately set the framework for the act of communication both within and across cultural and linguistic boundaries. In fact, the terminological aspect can be made to work most effectively only when seen within sound textual practice." (1998: 2) 
these is valuable for the translator. However, knowledge of the relevant terminology and text type conventions of a technical text is not enough to produce a successful translation.

Translation-oriented text typologies have done much harm, however, text typologies may be relevant to the extent that they are sufficiently detailed to provide any real help - but we do have a dilemma. As stated by Hatim \& Mason (1990: 138) too broad text type categories have no predictive value:

"Yet when attempts are made to narrow the focus of description, we run the risk of ending up with virtually as many text types as there are texts."

When all comes to all we do not get a free translation strategy by assigning a given technical text to a particular text type. A translation strategy must be laid down for any individual text to be translated (be it technical, literary or legal). The fact that a text to be translated belongs to a certain linguistic area is of course interesting to the translator, but it is only one factor among many important ones.

\section{Conclusion}

It is beyond questioning that many technical texts do possess what I have called the traditional features to a greater or lesser degree. My point is that they contain other features as well which may be just as important and which reveal other functions in the text than purely iformative ones - features which the stereotypical view ignores completely.

It is of utmost importance for the translator to understand the various purposes of a text and in the optimum situation to be able to discuss strategies with the author of the text. The keyword for a successful translation is awareness of all the purposes of a text. Also, the translator should be aware of the fact that in reality there is no such thing as a "technical text" - it is not a genre - but rather a number of texts making use of "technical language" and belonging to a great variety of genres.

Contrary to the traditional view technical texts are often highly expressive and also persuasive, but in a worst-case situation only the informative function is expected by the translator and only the informative function is translated! 


\section{References}

Baakes, K. (1994). Key issues of syntax in the special languages of science and technology. Julius Groos Verlag.

Bell, R.T. (1991). Translation and translating. Longman.

Brown, V.J. (1996). Persuasiveness and audience focus in a nonacademic R\&D Setting. In Journal of Technical Writing and Communication 26 (1). 37-55.

Gottlieb, H. (1994). Tekstning. Synkron billedmedieoversattelse. Center for Oversættelse, Københavns Universitet.

Göpferich, S. (1995). A pragmatic classification of LSP texts in science and Technology. In Target 7 (2). 305-326.

Hatim, B. and Mason, I. (1990). Discourse and the translator. Longman.

Hatim, B. (1998). Culture in scientific and technical communication: A dynamic view from a translation perspective. Unpublished.

Hoffmann, L. (1991). Texts and text types in LSP. In Schröder, H. (ed.). Subjectoriented Texts. Walter de Gruyter. 158-166.

Korning Zethsen, K. (1997). Expressivity in technical texts - from a Translation Theoretical Perspective. Handelshøjskolen i Århus.

Laurén, C. (1998). Shift of perspective in scientific texts: A study of idiolect. In Lundquist et al. (eds.). LSP Identity and interface. Research, knowledge and society. Proceedings of the 11th European Symposium on Language for Special Purposes 1. 463-472. Samfundslitteratur.

Munck, L. (1994). Introduktion til dansk teknisk sprogbrug. In Hjørnager Pedersen, V., Krogh-Hansen N. (eds.). Oversattelseshåndbogen. Munksgaard. 139-71.

Myers, G. (1989). The pragmatics of politeness in scientific articles. In Applied Linguistics 10 (1). 1-35.

Newmark, P. (1969). Some notes on translation and translations. In The Incorporated Linguist 8 (4). 79-85.

Newmark, P. (1988). A Textbook of translation. Prentice Hall International (UK) Ltd.

Nord, C. (1991). Text analysis in translation. Rodopi.

Norlyk, B. (1994). Fagsproglig kommunikation eller miskommunikation: et praktisk perspektiv på anvendelse af fagsprog. In Grindsted, A. (ed.): Fagsproglig kommunikation, HHS Jubilæumsskrift, bind 3. Samfundslitteratur. 24-33

Reiss, K. (1971). Möglichkeiten und Grenzen der Übersetzungskritik. Hueber.

Savory, T. (1968). The art of translation. Jonathan Cape.

Snell-Hornby, M. (1988). Translation studies. An integrated approach. John Benjamins Publishing Company.

Wilss, W. (1996). Knowledge and skills in translator behaviour. John Benjamins Publishing Company. 
